\title{
Developing an Organic Production System for Highbush Blueberry
}

\author{
William Sciarappa ${ }^{1}$, Sridhar Polavarapu, James Barry, Peter Oudemans, Mark Ehlenfeldt, \\ Gary Pavlis, Dean Polk, and Robert Holdcraft \\ School of Environmental and Biological Sciences, Department of Agriculture and Resource Management \\ Agents, Rutgers University, New Brunswick, NJ 08901
}

Additional index words. sustainable agriculture, integrated pest management, organic crop methods, Vaccinium corymbosum, smallfruit

\begin{abstract}
Four significant developments have occurred that amplify opportunity for certified organic growers to grow highbush blueberry (Vaccinium corymbosum) successfully. First, there is the 2002 U.S. Department of Agriculture national organic standard that defines organic production practices and crop labels that creates clarity and evens competition. Second, we have the continued increase of smallfruit and vegetable sales related to nutritional and human health reasons and the related market perception valuing organic produce more highly. Third, new tools are becoming available to organic growers that reduce the risk from pest problems such as the recent Organic Materials Review Institute listing of spinosad registered as a wettable powder (Entrust) and a fruit fly bait (GF-120 NF Naturalyte). Finally, the Rutgers Blueberry Working group has made considerable progress in refining integrated pest management practices and in developing new tools for organic production systems. This "work-in-progress" is investigating alternative approaches to some current agricultural practices in soil building, fertility, cultural approaches, and pest management. The authors' 7-year program has demonstrated organic methods in managing new sources of mulch, two key insect pests, two common diseases, and several weed species in establishing a commercial organic production system for highbush blueberries. As a programmatic result, organic acreage in New Jersey has increased from 0 to more than 150 acres, and more than 40 organic growers have adopted parts of this holistic production system in North America.
\end{abstract}

When blueberries were first selected from the forests of New Jersey and cultivated in the early 1900s, the traditional culture of this native smallfruit was essentially organic in nature. Commercial examples of organic horticulture being used today include selection for resistant varieties, adding organic amendments in building soil such as peat and humus, raised mounds for disease suppression, mulching for weed control and water conservation, "rogueing" of infected plants, pruning for canopy ventilation to reduce disease incidence, and the use of natural plant protection products that are relatively safe to beneficial insects (Childers and Lyrene 2006, Eck 1988, Pritts and Hancock 1992).

In contrast to other cultured fruits that have been introduced from foreign countries, the blueberry is one of the few native American fruits. This indigenous crop has relatively good natural resistance to pests and an inherent vigor because it has been domesticated for less than 100 years. Thus, there is this strong historic baseline for succeeding in the return to organic production, although some key risk factors remain to be solved. To achieve this holistic vision of an integrated

\footnotetext{
We thank the following people and agencies for their technical advice, horticultural discussions, and funding support: Sustainable Agriculture Research and Education; Natural Resource Conservation Service; New Jersey Department of Agriculture; Northeast Organic Farming Association of New Jersey; Agricultural Agents Association of New Jersey; Rutgers Cooperative Research and Extension; Rutgers Blueberry Working Group; and blueberry growers, especially Mike, Susan, and John Marchese; David Size; and Bobby Galetta.

${ }^{1}$ To whom reprint requests should be addressed; e-mail Sciarappa@rcre.rutgers.edu
}

organic system, specific obstacles to commercial production were addressed in conjunction with the applied Rutgers research team stationed at the Philip E. Marucci Cranberry and Blueberry Research Center.

\section{OVERVIEW}

Four recent developments significantly amplify opportunity for certified organic growers to grow organic highbush blueberry (Vaccinium corymbosum) successfully and to increase or transition certified acreage. First, there is the recent U.S. Department of Agriculture (USDA) national organic standardization that defines organic production practices and crop labels (USDA-NOP, 2002) that creates clarity and evens competition. Second, we have the continued increase of smallfruit and vegetable sales related to nutritional and human health reasons (Brazelton, 2004) that strongly contribute in creating today's $\$ 83,720,000$ highbush blueberry market in New Jersey. (Joshua, 2006). Future gains in this emerging agribusiness segment are promising through the "organic certification" process. This USDAcertified organic designation appeals to today's consumer as an even higher value and creates a separate market segment above the fresh market mainstream. Third, new organic tools are becoming available that reduce the risk from pest problems such as the recent Environmental Protection AgencyNational Organic Program registration of spinosad, now known as Entrust in the organic trade. Finally, the Rutgers Blueberry Working Group has made considerable progress in refining standard integrated pest management (IPM) practices and in helping develop new tools for organic production systems.
Conventional growers are switching from conventional to organic production in record numbers. Certified organic operations have doubled during the past 10 years and now stand at over 12,200 farms in the United States (Organic Trade Association, 2006). More than $5 \%$ of apples, $10 \%$ of California strawberries, and $15 \%$ of West Coast grapes are organic, and an increase from 0 to 150 acres of organic blueberries in the New Jersey area has occurred within the past 6 years (Sciarappa, 2003). In the northeastern U.S. market, a $4.5 \mathrm{~kg}$ flat of organic blueberries will return $\$ 18$ to $\$ 25$ compared with $\$ 8$ to $\$ 14$ for conventional product. This economic situation creates a strong incentive to transition toward organic agriculture, especially if a production system has well-defined procedures, manageable risks, and appropriate returns.

\section{OBJECTIVES}

The general goals of this 7-year program were to fill the primary production gaps in organic blueberry production with sciencebased research, to reduce risk and help develop an integrated crop management system for organic growers not only in New Jersey (where the trials were conducted), but to use applicable parts and conceptual approaches in any production area. The main objectives were to investigate viable solutions for organic weed, insect, and disease management; and to compile, compare, and incorporate proven horticultural practices into a sustainable production system for highbush blueberry.

\section{MATERIALS AND METHODS}

From 2000 to 2006, numerous field trials, farm demonstrations, laboratory tests, and extension outreach programs were conducted 
in organic blueberry production systems. Extensive literature reviews compared both conventional and organic smallfruit production practices. Replicated research trials and field demonstrations were initiated at two recently certified organic blueberry farms: Blueberry Acres, a 14-ha site (35 acres) in Wall Township, NJ; and Emery's Blueberry Patch, a 16-ha (40 acres) site in New Egypt, NJ. Commercial demonstrations of organic production techniques were also encouraged at five other farms. Laboratory trials and varietal comparisons of disease susceptibility were conducted at the Cranberry and Blueberry Research Center in Chatsworth, NJ. Fruit harvest infection rates were assessed at the Rutgers Fruit Research and Education Farm in Cream Ridge, NJ.

Insect pest experiments. Field trials were used to assess the activity of different organic listed insecticides on blueberry maggot (Rhagoletis mendax Curran) (Barry et al., 2005). The four organic insecticides evaluated were GF-120 NF Naturalyte Fruit Fly Bait (1.46 L·ha ${ }^{-1}, 20 \mathrm{fl} \mathrm{oz} /$ acre, Dow AgroSciences), PyGanic 1.4EC (2.34 L $\cdot \mathrm{ha}^{-1}, 32 \mathrm{fl}$ oz/acre, McLaughlin Gormley King Company), AgroNeem (4.68 L.ha ${ }^{-1}, 64 \mathrm{oz} /$ acre, Agro Logistic Systems), and Entrust (146 $\mathrm{mL} \cdot \mathrm{ha}^{-1}, 2$ oz/acre, Dow AgroSciences). The study was conducted in a recently certified blueberry field, located in Tinton Falls, NJ. Blueberry bushes were $\approx 2 \mathrm{~m}$ in height and spaced $1.2 \mathrm{~m}$ within and $2.7 \mathrm{~m}$ between rows. Treatment plots were $30.5 \times 91.4 \mathrm{~m}(\approx 0.28$ ha) and were replicated three times.

Each insecticide, except GF-120, was mixed with $233.8 \mathrm{~L} \cdot \mathrm{ha}^{-1}$ (25 gal) of water/ acre and sprayed using a commercial (airblast) mist blower to both sides of bushes. GF-120 was mixed at a ratio of $1: 5$ with water for $8.76 \mathrm{~L} \cdot \mathrm{ha}^{-1}$ (120 oz of mix/acre), and applied to one side of every row using an ATV Olive Fruit Fly Sprayer (PBM Supply \& Mfg, Chico, CA). This ATV sprayer had a 94.6-L tank, a nonadjustable 100-psi pump, and two nozzles from airblast sprayers consisting of discs (D-3 orifice) without the core. Insecticide treatments were applied on 7, 15, 22, and 29 Jul 2003. Adult blueberry maggot fly presence was assessed twice a week for 6 weeks using four Pherocon AM traps baited with ammonium acetate (Great Lakes IPM, Vestaburg, MI) per plot. Larval presence was determined on three dates (24 and 31 July, and 12 Aug.) by randomly selecting 1000 berries in center rows from each plot and boiling fruit with a microwave (Pickett and Spicer, 1931). Maggots extracted from these samples were counted.

Methods for the pheromone disruption trials with oriental beetle (Anomala orientalis Waterhouse) were initiated in 2002 (Sciarappa et al., 2005). Experimental plots were 0.8 ha in size with three replications. Test areas were saturated with oriental beetle pheromone, and reductions in male beetle captures and larval density were recorded. For adults, Japanese beetle traps were baited with $300 \mu \mathrm{g}$ (Z)-7 tetradecen-2-one. ChemTica dispensers and red rubber septa were loaded with 1 and $0.1 \mathrm{~g}$ of the oriental beetle sex pheromone respectively. For larval estimates, sentinel host plants were used with tethered virgin females to assess the level of mating and efficacy of communication disruption. Five potted blueberry plants were used with 10 virgin females. Each pot was placed close to the center of the plots. Numbers of oriental beetle grubs in each pot were determined in late September by destructive sampling. In 2003, the same pheromone loading rate per disrupter was used, but at a lower density of disrupters per hectare Adult females were individually placed in 30-mL cups with moist sand, and fertility status of oviposited eggs was monitored.

Disease experiments. Preliminary research studies were initiated for both inseason and postharvest disease problems. In 2003, an eight-treatment organic fungicide field trial was applied at the Blueberry Acre test site against early-season gray mold (Botrytis spp.) in three different blueberry blocks: two newly restored blocks of 'Bluecrop' and a 35-year-old block of 'Bluecrop'. Duplicate trials were conducted at Emery's Organic farm in a newly planted 3-year 'Duke' varietal block and a 40-year-old block of 'Blueray'. Methods for the organic fungicide field trials included a backpack sprayer which used a $1.83-\mathrm{m}$ boom with four T-Jet 8004 nozzles. Treatments were replicated four times and the plot size was $1.83 \times 7.62 \mathrm{~m}$ over the blueberry row. Treatments included the recommended rates for Serenade, Neem, Bordeaux mix, sulfur (S), oxidate, compost tea drench, and compost tea spray compared with an untreated control. Treatment materials were applied at 70 psi and 20 GPA. The first seasonal applications began between 3 to 5 June 2003 at the late flowering stage followed 7 to $8 \mathrm{~d}$ later at the early fruit stage, 9 to $11 \mathrm{~d}$ later at the midfruit stage, and 10 $\mathrm{d}$ later at the late fruit stage. Harvest evaluation was from 8 to 12 July 2003 .

For the laboratory tests, anthracnose spores (Colletotrichum acutatum) were applied over field-collected berries and then fungicidal treatments were topically applied.
Percent fruit infection was evaluated 2 weeks after application and subsequent growth of the pathogen.

Weed experiments. In-row trials in weed management used a 1-acre block of newly planted highbush 'Duke' blueberries. Four replicates in a randomized block design of eight mulching treatments were applied in $0.91 \times 4.57-\mathrm{m}$ plot sizes and evaluated over a 2-year period. Mulching treatments included composted pinewood, hardwood, coffee grinds, cocoa grinds, and leaf compost with or without underlying landscape fabric.

Methods for trials in walkway weed management used strips of two fine fescue turfgrasses: a hard fescue, (Festuca longifolia) cv. Warwick' and a chewings fescue, (Festuca rubra) cv. Truffa. These turfgrasses were established on 5 May 2003 in a newly planted organic blueberry block. Weed numbers, turf growth, and species composition were evaluated with regard to groundcover percentage and species composition, all in four replications with treatment size $1.52 \times$ $7.62 \mathrm{~m}$ over a 2 -year period.

\section{DISCUSSION AND RESULTS}

\section{Varietal selection}

When choosing specific blueberry cultivars to plant, an organic grower especially needs to consider disease resistance as importantly as yield, maturity, chilling requirements, berry size, color, and taste. Cultivars show considerable differences in susceptibility to some key diseases. Disease types and intensity may vary in each section of the county, region, or country. Information from university breeding programs provides comparative information that helps to decide upon the best adapted cultivar for a particular area. Nursery stock producers and transplant catalogues provide information on cultivar disease tolerance. Comparative results for cultivar tolerance to several key diseases from a long-term, ongoing USDA research project in Chatsworth, NJ, are shown in Table 1 (Ehlenfeldt, 2002).

Table 1. Relative responses and percentage fruit infection of 26 major cultivars to mummy berry blight, mummy berry fruit rot, anthracnose fruit rot, and other diseases under high-inoculum conditions.

\begin{tabular}{|c|c|c|c|c|}
\hline Cultivar & $\begin{array}{l}\text { Mummy } \\
\text { blight }^{2}\end{array}$ & $\begin{array}{l}\text { Mummy } \\
\text { fruit rot }^{z}\end{array}$ & $\begin{array}{l}\text { Anthracnose } \\
\text { fruit } \operatorname{rot}^{z}\end{array}$ & Miscellaneous observations \\
\hline Weymouth & $35.1, \mathrm{M}$ & $10.9, \mathrm{~L}$ & $31.5, \mathrm{~L}$ & \\
\hline Bluetta & $19.1, \mathrm{~L}$ & $20.2, \mathrm{M}$ & $81.6, \mathrm{H}$ & Extremely RRSV susceptible \\
\hline Chanticleer & $27.1, \mathrm{M}$ & $10.0, \mathrm{~L}$ & 74.7, $\mathrm{H}$ & \\
\hline Duke & $5.5, \mathrm{~L}$ & $17.4, \mathrm{M}$ & $48.7, \mathrm{M}$ & Some RRSV, suspect to stem blight \\
\hline Spartan & $37.8, \mathrm{M}$ & $22.2, \mathrm{H}$ & $74.2, \mathrm{H}$ & \\
\hline Bluejay & $9.9, \mathrm{~L}$ & $9.6, \mathrm{~L}$ & $47.4, \mathrm{M}$ & \\
\hline Bluehaven & $100.0, \mathrm{H}$ & $39.0, \mathrm{H}$ & - & \\
\hline Blueray & $43.4, \mathrm{H}$ & $33.9, \mathrm{H}$ & $71.5, \mathrm{H}$ & Susceptible to RRSV \\
\hline Bluecrop & $34.6, \mathrm{M}$ & $21.9, \mathrm{M}$ & $79.8, \mathrm{H}$ & \\
\hline Reka & $22.0, \mathrm{M}$ & 4.9, L & $52.0, \mathrm{M}$ & \\
\hline Legacy & $33.3, \mathrm{M}$ & $21.7, \mathrm{M}$ & $34.3, \mathrm{~L}$ & \\
\hline Jersey & $7.8, \mathrm{~L}$ & $23.8, \mathrm{H}$ & $38.9, \mathrm{~L}$ & \\
\hline Rubel & $12.3, \mathrm{~L}$ & $27.4, \mathrm{H}$ & $44.2, \mathrm{M}$ & Susceptible to stunt, resistant to RRSV \\
\hline Brigitta Blue & $16.3, \mathrm{~L}$ & $9.7, \mathrm{~L}$ & $16.7, \mathrm{~L}$ & Susceptible to scale insects, leafy in fall \\
\hline Elliott & $4.0, \mathrm{~L}$ & $37.3, \mathrm{H}$ & $12.5, \mathrm{~L}$ & \\
\hline
\end{tabular}

${ }^{\mathrm{z}}$ Disease severity evaluations: L, low; M, medium; H, high.

Minimum of 2 years of data, normalized to selected standards.

RRSV, red ring spot virus. 


\section{Weed management}

Weed control ranks as the number one problem in both conventional and organic blueberry production (Majek, et al., 2004). Young blueberry plants have a long establishment period and are poor competitors against weeds for moisture, nutrients, and sunlight. Weedy fields have been shown to reduce fruit yields and growth significantly (Yarborough and Marra, 1997). A 75 to $150-\mathrm{cm}$-wide weed-free strip is essential for good crop growth. Even in well-established blueberries, weeds remain a major factor in economic success or failure.

Mulch types include pine bark, hardwood, municipal leaves, and sawdust (Johnson, 1996; Magee and Spiers, 1995); cranberry leaves, coffee grinds, cocoa grinds, composted tea leaves, and food from industry by-products (Sciarappa, 2003). About 4 to 8 $\mathrm{cm}$ of these mulches as a $76-\mathrm{cm}$ band under each plant (Cuddy, 1997) should provide a weed control level of around 95\%. Results of our two-season experiment with many of these mulch materials are shown in Fig. 1, which compares these mulches with and without landscape fabric against key weeds in a new commercial planting of 'Duke' highbush blueberry. In combination with black landscape fabric, weed control can become almost complete.

Weed suppression in the walkways can be achieved by establishing fine-leaf fescue turf and monthly mowing (Marchese, 2003). These new fescue cultivars are very low, slow growing, and need only a few mowings throughout the entire season compared with standard turfgrass species. The results of our trials clearly showed the steady weed suppression and coverage increase over time allowed by both 'Warwick' hard fescue and 'Tuffa' chewings fescue cultivars (Fig. 2). Once established, this group of "cover crops" can outcompete weeds by exuding allopathic herbicidal substances through their roots that act as natural herbicides.

In established blueberry blocks at two organic farms, regular mowings alone gradually changed a mixed stand of broadleaf weeds to a native perennial grass cover in New Jersey. At our previously abandoned site, Blueberry Acres, a 2-year mowing regime on a regular 3-week basis converted a diversity of weeds in the walkways into a $95 \%$ stand of native grass species whereas unmowed adjacent strips remained relatively unchanged in weed species composition. Notill, fall-planted turfgrass cultivars will also cover the orchard floor, which first must be closely mowed and no-tilled or tilled and slit seeded. These methods of establishment develop a solid grass stand that allows equipment and customer traffic in wet spring periods. With bare ground middles, regular cultivation will uproot small germinating weeds and provide weed-free middles. Within a crop row with overhead irrigation, the tractor-mounted, hand-maneuvered rotary cultivator is very effective at navigating between blueberry plants and removing weeds with shallow cultivation. If the grower uses
Mulching Trial

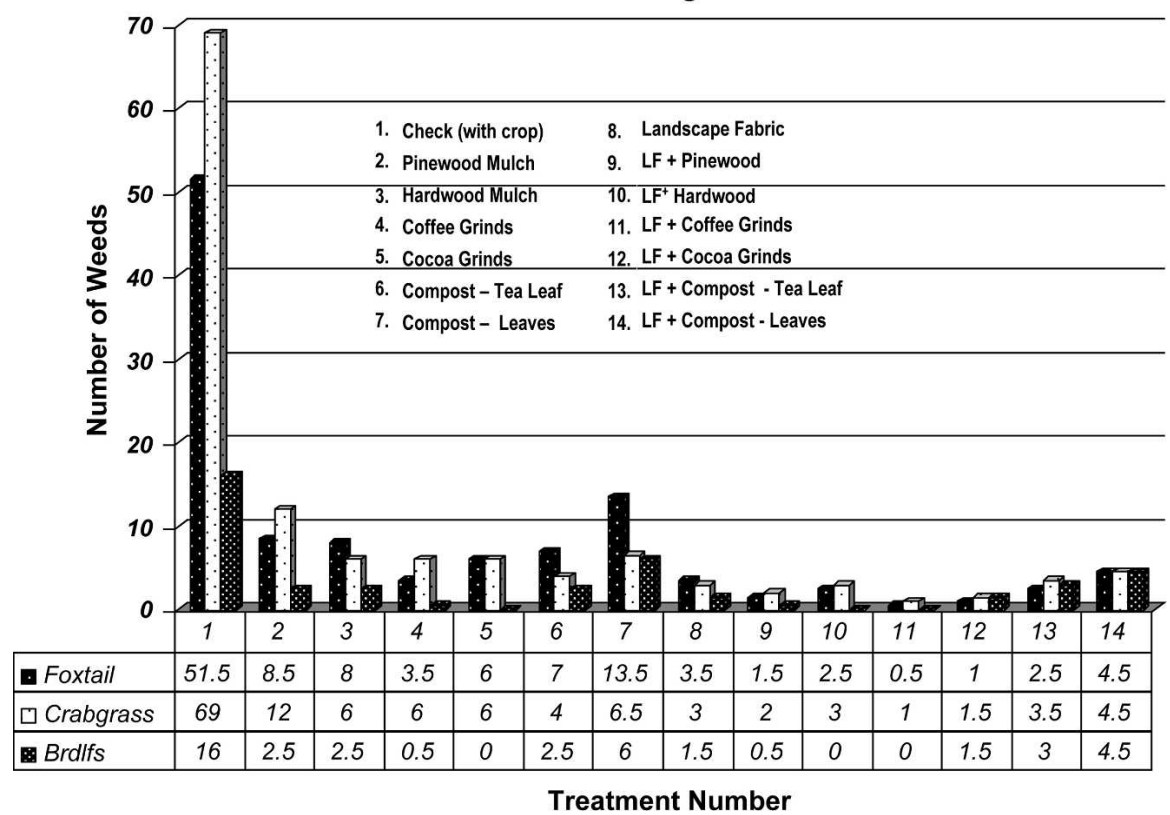

Fig. 1. Weed populations of hairy crabgrass, foxtail species, and broadleaf weeds with mulch application of pinewood, hardwood, coffee grinds, cocoa grinds, and leaf compost with and without underlying landscape fabric (LF).

trickle irrigation and wishes to use rotary cultivation, the drip tube must be buried permanently or temporarily lifted up without water. Hand hoeing may be needed with any in-row technique, which is also used in conventional methods.

\section{Insect management}

Prevention and detection are the keys to organic blueberry insect management. Rutgers blueberry IPM currently serves more than 50 blueberry growers and makes considerable use of pheromone and attractant monitoring traps (Polk, pers. comm., 2005). If pest populations begin to rise, management decisions can be made with regard to economic thresholds where the use of an appropriate conventional or organic insecticide may be knowledgeably considered. Significant pesticide amounts have been reduced with IPM in New Jersey, and documented with cost savings as well as providing environmental benefits.

\section{Organic tools}

The organic toolbox has developed a good selection of NOP-approved materials, old and new. For good efficacy, these materials must be applied early in the pest cycle, sprayed with good coverage, and reapplied as needed. Most organic substances are short lived, nonpersistent, weather dependent, and relatively selective in nature. Table 2 compares four Organic Materials Review Institute (OMRI)-listed insecticides that are EPA registered and economically justified during the growing season against many important insect pests (Barry, et al., 2005).

During the nongrowing season, the use of dormant oils on the bark smothers overwintering scale insects (Families: Diaspididae

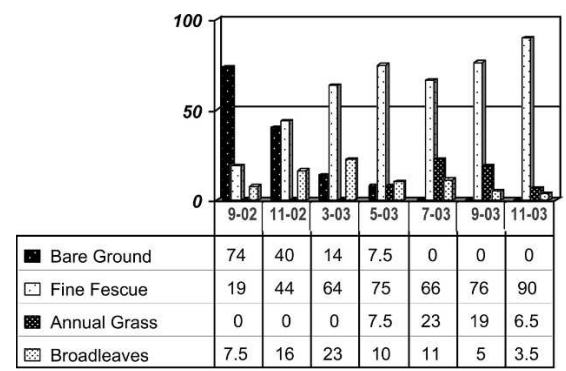

Fig. 2. Percent groundcover.

and Coccidae) and bud mites (Acalitus vaccinii). In springtime, neem-based sprays can also reduce any surviving scale and bud mites. Older plantings may develop an infestation of white grubs like Japanese Beetle, European Chafer and Oriental Beetle feeding on roots below ground. Biocontrol agents can be used like milky spore disease (Bacillus popilliae) and parasitic nematodes in the soil to help manage these underground pests as well as using pheromone traps.

Several lepidopteran species of moth larvae emerge from eggs in June. Large populations of these caterpillars can quickly damage blueberry fruit and foliage. Bacillis thuringiensis spray is recommended at this early time. Bacillis thuringiensis is an effective biological toxin derived from various bacterial strains that control young worms (Polavarapu and Peng, 1997). Soon after ingestion, caterpillars will stop feeding and then gradually die. Larger larvae may be managed with pyrethrum sprays like PyGanic. This plant-based neurotoxin is effective against many other insects and is relatively safe to natural enemies. 
Table 2. Organic insecticide trial.

\begin{tabular}{llccccc}
\hline $\begin{array}{l}\text { Trade name } \\
\text { formulation }\end{array}$ & $\begin{array}{c}\text { Active } \\
\text { ingredient }\end{array}$ & Rate/acre & Reentry (h) & PHI (d) & Price & Price/spray $(\$)$ \\
\hline PyGanic 1.4 EC & Pyrethrin & $18 \mathrm{oz}$ & 12 & 0 & \$150/gal & 21 \\
Agroneem 15 F1 & Azadiractin & $2 \mathrm{qt}$ & 0 when dry & 0 & @21/qt & 42 \\
Entrust 80 WP & Spinosad & $2 \mathrm{oz}$ & 4 & 3 & $\$ 400 / \mathrm{b}$ & 50 \\
GF120 Bait & Spinosad & $20 \mathrm{oz}$ & 4 & 0 & \$80/gal & 14 \\
\hline
\end{tabular}

PHI, preharvest interval.

There is another side benefit to "going organic" and avoiding synthetic insecticides. Secondary pests often do not "explode" into major problems like they do in conventional fields where all the beneficial predators, parasites and pollinators have been killed by calendar spray schedules of broad-spectrum organophosphate and carbamate insecticides. More selective organic insecticides maintain survival of these beneficial arthropods that then biologically suppress secondary pests like aphids (Family: Aphididae) and leafhoppers (Family: Cicadellidae). Large populations of sucking pests not only injure by withdrawing plant juices but can spread viral diseases. If these vascular feeders escape biological control and do begin to increase population numbers significantly, applications of Stylet oil or soap-based insecticides can clog their mouth parts or smother them. Preventative practices include supplementing beneficials by planting border rows of preferred small-flowered plants like dill, mint, and alfalfa. Adult beneficials feed on these nectar, pollen, and sap food sources to reproduce rapidly and then seek out plantfeeding pests like aphids, whiteflies, and thrips.

\section{Blueberry maggot trials.}

Blueberry maggot fly is the number one insect problem in commercial highbush blueberry in New Jersey (Marucci, 1996) and is especially problematic in organic cultivation. Consumers are unlikely to be repeat customers in discovering large, white wiggling maggots in the middle of their blueberries. The maggot is the legless "immature" stage of the adult fly. Early season varieties like 'Earliblue', 'Bluetta', and 'Weymouth' can nearly escape maggot infestation because they come to harvest before most of the blueberry maggot adults are ready to lay eggs. On the other hand, midseason varieties like 'Duke' and 'Bluecrop' are much more susceptible. Both organic and conventional farmers use either a calendar-based or an IPM-based spray program to control $R$. mendax. A calendar-based approach recommends growers start spraying insecticides within $10 \mathrm{~d}$ of the first detection of an adult fly in the area, and continue spraying at 7- to 10-d intervals until the end of harvest. Alternatively, an IPM-based program recommends growers to monitor the presence of adults using ammonium acetate-baited sticky traps. A recommended insecticide should be applied within $5 \mathrm{~d}$ of the date of capture of a single fly in any one of the monitoring traps, followed by a second spray 7 to $10 \mathrm{~d}$ later. This spray interval should be repeated for each subsequent fly detection until the end of harvest.

A newly registered insecticide material is spinosad, a by-product of a soil bacteria Saccharopolyspora spinosa Mertx and Yao, which is effective against various fruit flies, thrips, and other pests. Spinosad formulations called Entrust and GF-120 Fruit Fly Bait have been labeled for organic blueberry growers as a result of our efficacy research. Entrust also has activity on caterpillars and thrips. This sprayable formulation is applied $10 \mathrm{~d}$ after the first adult maggot flies are captured in yellow sticky traps used in an IPM program. Airblast sprayer applications are made at $147 \mathrm{~mL}$ product per ha with $200 \mathrm{~L} \cdot \mathrm{ha}^{-1}$. Two more applications 7 to 10 $\mathrm{d}$ apart may be needed if populations continue to emerge.

The other spinosad formulation called GF-120 NF Naturalyte Fruit Fly Bait is formulated exclusively for fruit fly control. This formulation contains sugars known to enhance feeding (Barry and Polavarapu, 2004). Thus, lower dosages of spinosad bait act as a stomach poison when ingested versus the contact action of a broadcast spray. The bait is now commercially available as GF120 NF Naturalyte Fruit Fly Bait, has ammonia-based attractants, a sucrose feeding stimulant, and a toxicant (spinosad). GF-120 also shows promise as a perimeter spray when pest populations invade from adjacent fields or forests. Perimeter treatments at Emery's Blueberry Patch showed a large decline in pest numbers both within the field and along the forest edge after a single well-timed application after adult emergence was detected with sticky traps.

These two formulations join other plantderived organic fruit fly materials, pyrethrin (PyGanic) and neem oil (Agroneem/Azadirect) to establish a rotational spray program. Pyrethrins are insecticides produced primarily in the flowers of a chrysanthemum Tanacetum cinerariaefolium L. Pyrethrin has good knockdown ability, but very short residual activity, because it degrades rapidly after exposure to sunlight.

Blueberry maggot field spray trial. Results from our large-scale field trials found there were significantly lower levels of fruitinfesting larvae in treated plots compared with the untreated control (Barry et al., 2005). GF-120 NF Naturalyte Fruit Fly Bait (spinosad bait), Entrust, and PyGanic were not significantly different from the positive synthetic control (imidacloprid). There was a significantly higher infestation in the plot treated with Agroneem (neem extract) compared with the positive control. There was no treatment effect for number of adult maggot flies captured in sticky traps, which indicated a steady threat of pest attack on maturing fruit. Although the efficacy of the spinosad spray in the midst of heavy pest pressure was clearly superior, growers should not rely on just one material but should switch to different chemical modes of action. Complete results of this replicated trial comparing these commercial compounds are shown in Table 3 and Fig. 3. Conscientious chemical rotation will avoid insect resistance and preserve the high efficacy level of spinosad.

Scarab beetle trials. Two recent breakthroughs in insect management are just becoming commercially available for these primary soil pests. New species of predatory nematodes have been discovered in New Jersey and have proved effective against various white grub species like Japanese beetle and Asian beetle (A. Koppenhofer, pers. comm.). These biological control agents against such underground pests have been commercialized and should be approved for organic production systems to augment or replace milky spore treatments.

Oriental beetle is the other major scarab beetle pest that dominates many northeastern blueberry fields. The oriental beetle, Anomala orientals (Waterhouse), is a major pest of blueberries, ornamental nurseries, and turfgrass in New Jersey, southeastern New York, Connecticut, and Rhode Island. Grubs voraciously consume blueberry roots underground. The sex pheromone of oriental beetle has been identified as a 9:1 blend of (Z)- and (E)-7-tetradecen-2-one (Zhang et al., 1994). The adult's pheromone has been shown to be extremely potent. Sex pheromone-mediated mate acquisition and copulation was found to occur at or near soil surface, shortly after emergence, close to the emergence site (Facundo et al., 1999).

The development of sprayable microencapsulated formulations (3M Canada, London, Canada) has facilitated permeation of oriental beetle pheromone near the soil surface where the adults fly, which further improved prospects for commercial efficacy of this organic technology (Polavarapu et al., 2001). Previous studies have indicated that percentage of reduction in trap captures [disruption index (DI)] in plots treated with

Table 3. Mating disruption-comparison of dispensers.

\begin{tabular}{lccccc}
\hline Treatment & $\begin{array}{c}\text { No. of } \\
\text { disrupters/ha }\end{array}$ & $\begin{array}{c}\text { No. of beetles } \\
\text { pretest }\end{array}$ & $\begin{array}{c}\text { No. of beetles } \\
\text { posttest }\end{array}$ & Disruption (\%) & Mated (\%) \\
\hline Control & 0 & $46.9 \mathrm{NS}$ & $340.8 \mathrm{~A}$ & 0 & 76.9 \\
Dispensers & 50 & $22.7 \mathrm{NS}$ & $6.6 \mathrm{~B}$ & 98.1 & 5.9 \\
Rubber septa & 50 & $37.8 \mathrm{NS}$ & $2.3 \mathrm{~B}$ & 99.3 & 0 \\
\hline
\end{tabular}

${ }^{\mathrm{N}}$ Nonsignificant. 


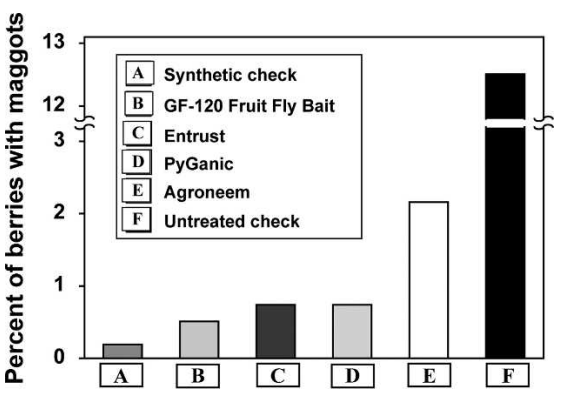

Fig. 3. Organic insecticide comparison.

the 9:1 blend of (Z)- and (E)-7-tetradecen-2one was comparable with reductions in trap captures among plots treated with (Z)-7 tetradecen-2-one alone at the same rates (Polavarapu et al., 2002). The sprayable formulation of (Z)-7-tetradecen-2-one, being a ketone, does not qualify for EPA tolerance exemptions of food crops, unlike the other arthropod pheromones containing acetate, alcohol, and aldehyde moieties. However, arthropod pheromones formulated in newly developed retrievable polymeric dispensers have been granted EPA tolerance exemption for use on food and nonfood crops because the active material is removed from the agricultural environment after the cropping season.

The main objective of these particular studies were therefore to compare the potential of retrievable reservoir-type plastic dispensers (ChemTica International, Costa Rica) and red rubber septa in disrupting pheromone-mediated communication of oriental beetle in highbush blueberries (Sciarappa et al., 2005)

The feasibility of disrupting sexual communication in oriental beetle was evaluated at the Emery blueberry site by placing 50 to 75 ChemTica dispensers/ha (50-75 g.ha ${ }^{-1}$ a.i.) that release (Z)-7-tetradecen-2-one, the major sex pheromone component of oriental beetle, or red rubber septa deployed at the same density, but loaded with only 5 to $7.5 \mathrm{~g}$ $\cdot \mathrm{ha}^{-1}$ a.i. in 2002 and 2003. During both years, pheromone trap captures in plots treated with dispensers and rubber septa were significantly lower compared with pheromone trap captures in untreated control plots. In 2002, significantly fewer grubs were found in plants placed in the two disrupter treatments compared with untreated control plots. In 2003, fewer females recovered from disrupter plots were found mated compared with females placed in untreated control plot. These field trials showed that retrievable traps dispense this pheromone evenly throughout the field, which confused the very large numbers of flying males and disrupted mating more than $95 \%$ (Fig. 4). Subsequently, egg laying by females was prevented and the next generation was largely eliminated.

These New Jersey studies are the first to indicate that sexual communication in oriental beetle can be disrupted by deploying retrievable dispensers that release high rates of pheromone at lower densities than pre- viously thought. In the commercial-size farm operation trials at Blueberry Acres, male oriental beetle captures had highly significant differences among various treatment plots. Before placement of disrupters in both 2002 and 2003, male beetle adult populations were not significantly different. Posttreatment trap captures were significantly lower in plots treated with ChemTica dispensers and rubber septa compared with trap captures in untreated control plots. Pheromone trap captures remained low in plots containing dispensers and rubber septa throughout the season compared with captures in control plots in both 2002 and 2003. The DI in 2002 and 2003 was similar, considering $33 \%$ fewer dispensers were used in 2003 (Table 4) relative to 2002 (Sciarappa, et al., 2005).

In 2002, grub density was compared in the following generation by retrieving sentinel blueberry plants tethered with 10 virgin females per plots. Significantly fewer grubs were found in blueberry plants placed in the two disrupter treatments than in the untreated control plots. In 2003, tethered virgin females were placed at a density of 40 per plot. Fewer than $50 \%$ of the virgin females were recovered after two nights in the field. Bird predation and escape of beetles from tethers were significant factors affecting recovery.

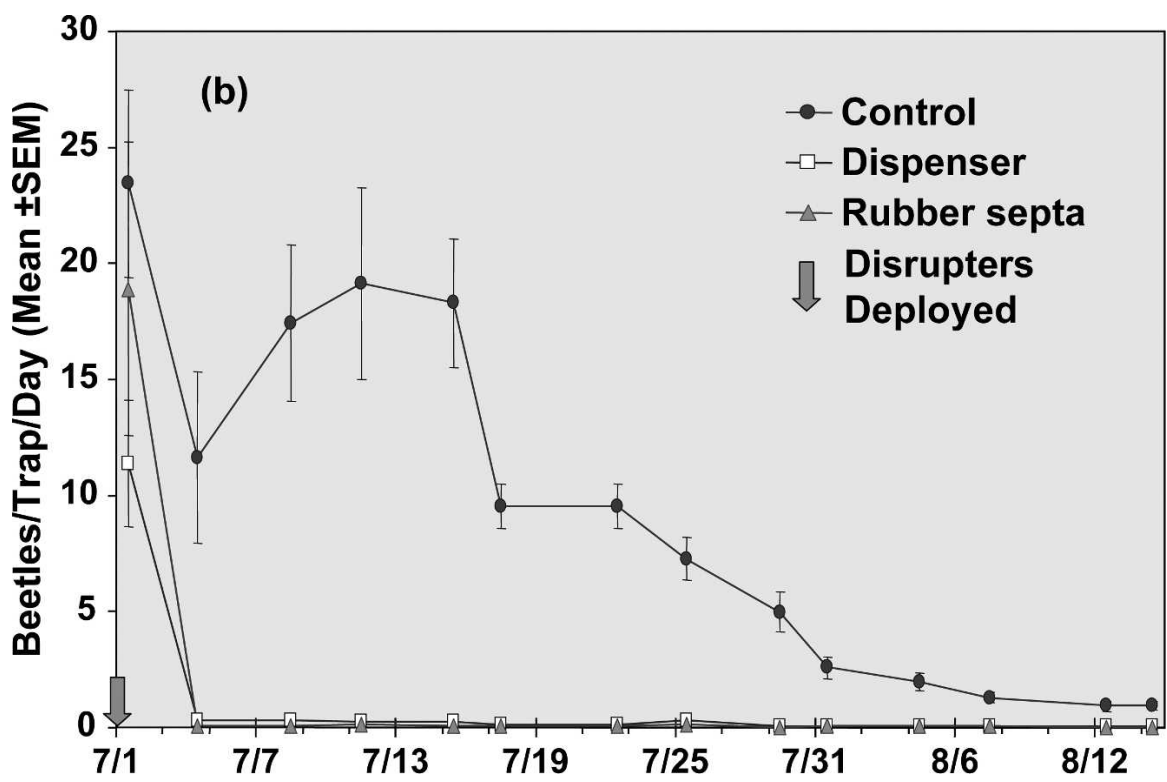

Fig. 4. Mating disruption trials for Oriental beetle.

Table 4. Insecticidal efficacy against blueberry maggot larvae.

\begin{tabular}{lcccc}
\hline & & \multicolumn{3}{c}{$\begin{array}{c}\text { Percent of boiled } \\
\text { blueberries with maggots }\end{array}$} \\
\cline { 2 - 5 } Treatment & Rate (oz/ac) & 24 July & 31 July & 12 Aug. \\
\hline Entrust & 2 & $0.57 \pm 0.20 \mathrm{bc}$ & $1.00 \pm 0.46 \mathrm{bc}$ & $0.67 \pm 0.34 \mathrm{bc}$ \\
GF-120 & 20 & $0.47 \pm 0.17 \mathrm{bc}$ & $0.53 \pm 0.03 \mathrm{c}$ & $0.53 \pm 0.22 \mathrm{bc}$ \\
Agroneem & 64 & $2.27 \pm 1.48 \mathrm{~b}$ & $2.30 \pm 1.08 \mathrm{~b}$ & $1.90 \pm 1.25 \mathrm{~b}$ \\
PyGanic & 32 & $1.03 \pm 0.34 \mathrm{bc}$ & $0.70 \pm 0.23 \mathrm{c}$ & $0.50 \pm 0.06 \mathrm{bc}$ \\
Provado & 6 & $0.3 \pm 0.06 \mathrm{c}$ & $0.23 \pm 0.08 \mathrm{c}$ & $0.03 \pm 0.03 \mathrm{c}$ \\
Untreated & - & $13.70 \pm 3.04 \mathrm{a}$ & $14.10 \pm 4.50 \mathrm{a}$ & $9.7 \pm 2.25 \mathrm{a}$ \\
F value & & 19.49 & 25.29 & 13.55 \\
$P$ value & & $<0.0001$ & $<0.0001$ & $<0.0001$ \\
\hline
\end{tabular}

Significantly fewer virgin females were found to oviposit fertilized eggs that were recovered from the two disrupter treatments compared with females in untreated control plots. Retrievable dispensers releasing high rates of pheromones deployed at low density appear to hold promise in disrupting sexual communication in oriental beetle, especially in food crops where residue data may be required for registration of sprayable pheromone formulations. Commercial demonstrations in 2004 clearly showed the efficacy on a large-scale basis. Such biorational strategies can be applied at other locations on additional crops and customized for different pest species.

\section{Disease management}

The organic grower cannot simply rely on synthetic fungicides sprayed on a calendar schedule to "save the day" in a disease emergency. When it comes to disease management, prevention of problems is again the key concept to use in an organic program. An outreach program with disease fact sheets allowed growers to learn how to diagnose disease symptoms from mummy berry and Botrytis accurately, and to anticipate certain climatic conditions, understand varietal tolerance, and adjust factors that feed pathogen 
growth to minimize crop susceptibility (Sciarappa and Oudemans, 2005a, b).

NOP-approved and Organic Materials Review Institute (OMRI)-listed fungicides will provide a safety net but cannot be relied upon alone. These compounds do not suffice by themselves and need to be bolstered by a good horticulturally based disease management program. Some of these fungicidal suggestions are very old standards like Bordeaux (a combination of the natural minerals $\mathrm{Cu}$ and lime) and others are very new materials like Serenade, a living, biological Bacillis subtilis.

\section{Disease management research}

The Botrytis fungicide trial data combine data from all five trials (Fig. 5). In general, Botrytis populations were moderate to quite high in the control. Similar results were seen in the compost tea drench treatments or compost tea foliar applications. Marginal results were also observed with neem based upon flower infection. Mediocre results in these five field trials were seen with $\mathrm{S}$, Bordeaux, and oxidate as seen in the mean values of disease control. The best flower protection against Botrytis was Serenade, which was consistent across all tests. Mummyberry was present but strikes were few and far between to get meaningful data. Also berry yields were too variable on a plant-by-plant basis to show significant differences in small plots.

Anthracnose postharvest trials in the laboratory also showed significant efficacy of Serenade over the other organic fungicides, but not as good as the synthetic standard (Fig. 6).

\section{SUMMARY}

From a horticultural and pest management standpoint, current tools can provide effective commercial control, reasonable cost, and environmental advantages (Table 2). A general pest management plan was devised to serve as a starting point for organic program development (Table 5). The reduced risk of this integrated system encourages rapid expansion of organic blueberry acreage. Similarly, conventional growers can more confidently switch to organic certification. Marketing insect-free fruit produced through sustainable organic programs provides a successful agricultural food chain model for consumers, growers, and the environment alike. These breakthroughs may just be the beginning of safer and more effective crop management and plant protection programs.

From a marketing perspective, more than 3000 ha of blueberries are grown in New Jersey with less than $2 \%$ volume produced organically. We believe that the agribusiness situation is that of an advanced market ahead of agricultural research; demand ahead of supply. The price of a flat of organic blueberries has ranged from $\$ 18$ to $\$ 28$ over the past 3 years whereas conventional production prices have generally

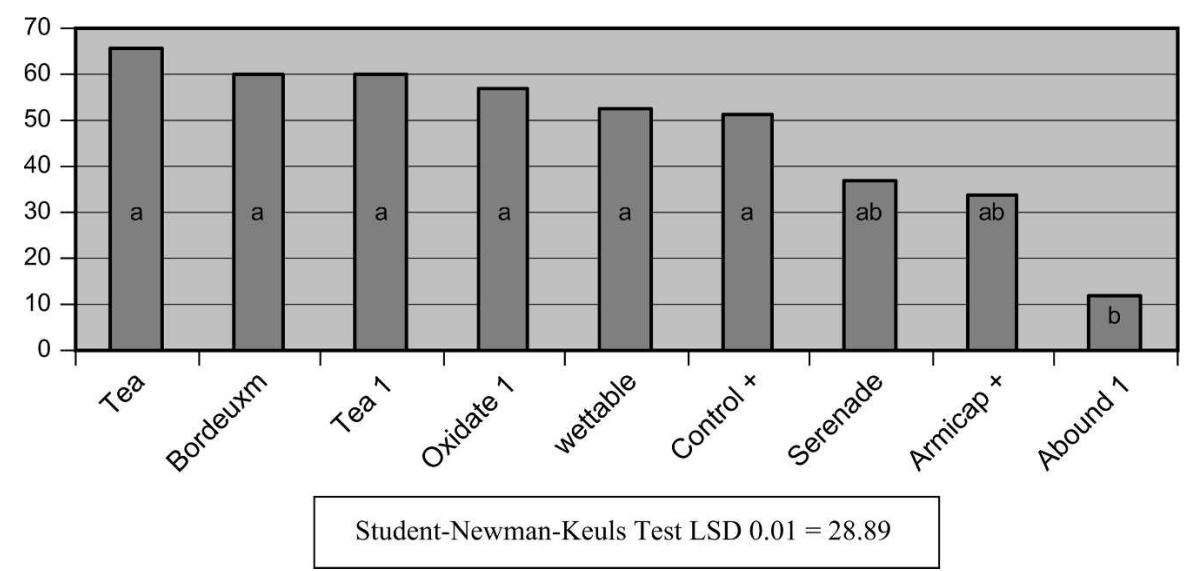

Fig. 5. Percentage control of anthracnose postharvest on fruit.

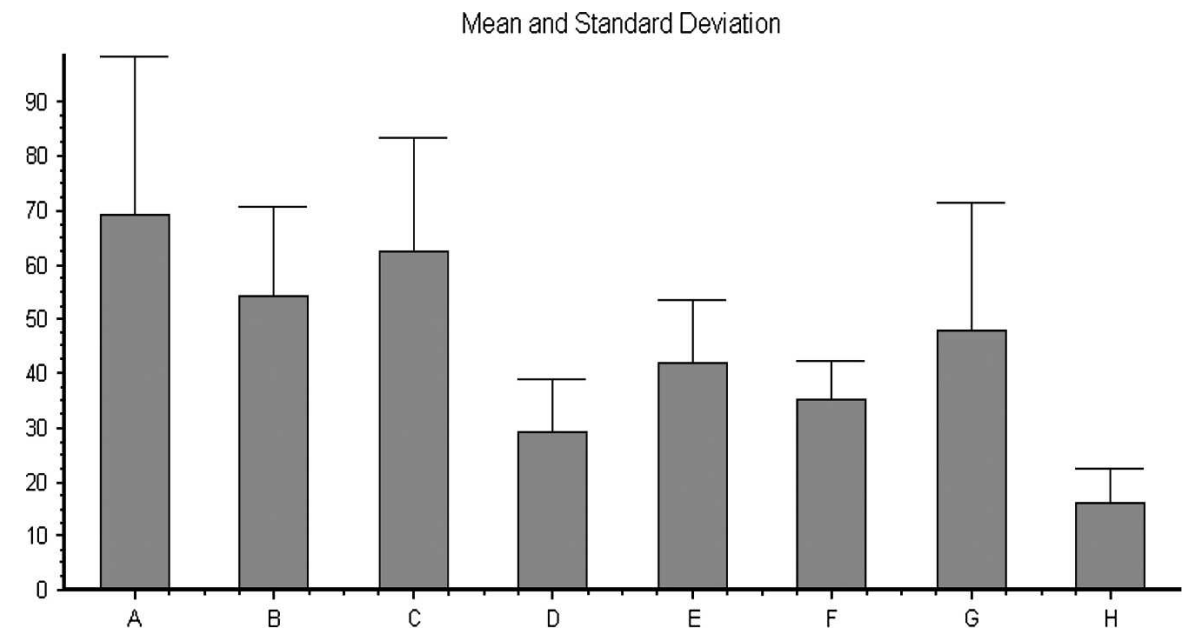

Fig. 6. Comparison of organic fungicides and number of flower clusters with botrytis strikes. A, check; B, compost tea spray; C, compost tea drench; D, oxidate spray; E, S spray; F, bordeaux mix; G, neem spray; H, Serenade spray.

Table 5. General plan-organic pest management.

\begin{tabular}{lll}
\hline Crop stage & \multicolumn{1}{c}{ Pest problem } & \multicolumn{1}{c}{ Management method } \\
\hline Dormant & Scale, phomopsis & Lime sulfur \\
& Botrytis, anthracnose & Prune old canes and twiggy wood \\
& Scarab beetle larvae & Milky spore, predaceous nematodes \\
& Curculio, weevil, fruit & Rotary hoe or rake middles and \\
worm, fruit fly & cultivate alleyways \\
Budbreak & Blueberry thrips & Entrust \\
& Mummyberry & Disc, rake, sweep, hoe, and mulch \\
& Weevils, curculio & Disc, rake, sweep, hoe, and mulch \\
Prebloom & Leafrollers, caterpillars & Bt's, Dipel; Javelin \\
& Scarab beetles & Milky spore, predaceous \\
Bloom & Botrytis blossom blight & nematodes, traps \\
Postbloom & Various diseases & Serenade \\
Fruiting & Blueberry maggot & Armicarb; Bordeaux; Serenade, rotation \\
& Blueberry maggot & GF120 bait, spinosad, perimeter sprays \\
& Leafrollers and caterpillars & Entrust; Agroneem; PyGanic, rotation \\
Leafhoppers and aphids & Bt's, Dipel; Javelin \\
Preharvest & Scarab beetles & Stylet oil, soap-type insecticides \\
& Birds and mammals & Pheromone disruption and \\
& Anthracnose & attractant traps \\
& Bud mite, scale & Netting, scare devices, dogs \\
& & Oxidate; Trilogy, clarified neem oil \\
& & Horticultural oil, neem oil, \\
& & prune old cane \\
\hline
\end{tabular}

ranged between $\$ 8$ to $\$ 14 /$ flat. Growers interested in transitioning to organic blueberries should read the chapter on organic blueberries in Blueberries for Growers,
Gardeners, Promoters (Childers and Lyrene, 2006) and may feel free to contact the lead author for advice and connection to the Rutgers team. 


\section{Literature Cited}

Barry, J.D. and S. Polavarapu. 2004. Feeding and attraction of blueberry maggot flies (Diptera: Tephritidae) to protein baits, ammonium acetate, and sucrose. J. Econ. Entomol. 97:1269-1277.

Barry, J., W. Sciarappa, and S. Polavarapu. 2005. Comparative effectiveness of different organic insecticides to blueberry maggot flies (Diptera: Tephritidae). J. Econ. Entomol. 98:1236-1241.

Brazelton, D. 2004. World blueberry production. Proc. Oregon Hort. Soc. <http://www.oregon horticulturesociety.org/>.

Childers, N. and P. Lyrene. 2006. Blueberries for growers, gardeners, promoters. E.O. Painter Printing, Gainesville, FL.

Cuddy, J. 1997. Replacing chemical weed control with mulch in commercial blueberries. SARE reporting system: FNC97-193: 1997 Annual report.

Eck, P. 1988. Blueberry science. Rutgers University Press, New Brunswick, NJ.

Ehlenfeldt, M. 2002. A survey of disease resistance in blueberry cultivars, old and new. USDA report.

Facundo, H.T., C.E. Linn, Jr., M.G. Billani, and W.L. Roelofs. 1999. Emergence, mating, and postmating behaviors of the Oriental beetle (Coleoptera: Scarabaeidae). J. Insect Behav. 12:175-192.

Johnson, D. 1996. The efficacy of red oak sawdust as a mulch to control grass and weeds in organic wild blueberries. SARE reporting system: FNE96-136: 1996 Annual report.

Joshua, T.M. 2006. 2006 Blueberry statistics. New Jersey Agricultural Statistics and New Jersey Department of Agriculture, Trenton, NJ.

Magee, J.B. and J.M. Spiers. 1995. Influence of mulching systems on yield and quality of southern highbush blueberries. In: R.E. Gough and R.F. Korcak (eds.). Blueberries: A century of research. Haworth Press, Binghamton, NY.

Majek, B., P.V. Oudemans, and S. Polavarapu. 2004. 2004 Blueberry pest control recommendations for New Jersey. Rutgers Coop. Ext. pub. no. E265.

Marchese, J. 2003. Emery's berry patch. Creating no-till cover in newly established organic blueberry blocks. SARE Reporting System: FNE03-476: 2003 Annual report.

Marucci, P.E. 1996. Insects and their control, pp. 199-235. In: P. Eck and N.F. Childers (eds.). Blueberry culture. Rutgers University Press, New Brunswick, NJ.

Organic Trade Association. 2006. <http://www. ota.com/organic/mt/business.html $>$.

Pickett, A.D. and E.C. Spicer. 1931. The blueberry maggot. N.S. Dept. Agr. Publ.

Polavarapu, S., G. Lonergan, H. Peng, and K. Niesen. 2001. Potential for mating disruption of Sparganothis sulfureana Clemens (Lepidoptera: Tortricidae) in cranberries. J. Econ. Entomol. 94:658-665.

Polavarapu, S. and H. Peng. 1997. Evaluation of insecticides against lepidopterous pests during bloom on blueberries, 1997. Anthropod Management Tests 22:52.

Polavarapu, S., M. Wicki, K. Vogel, G. Lonergan, and K. Nielsen. 2002. Disruption of Sexual Communication of Oriental Beetles (Coleoptera: Scarabaeidae) with a Microencapsulated Formulation of Sex Pheromone Components in Blueberries and Ornamental Nurseries. Environ. Entomol. 31:1268-1275.
Pritts, M. and J. Hancock (eds.) 1992. Highbush blueberry production guide. Northeast regional agricultural guide. Northeast Regional Engineering Service, Ithaca, NY.

Sciarappa, W.J. 2003. Ratcheting up commercial organic high-bush blueberry production systems. Sustainable Agricultural Research and EducationARE Reporting System: Project search results. ONE03-016.

Sciarappa, W. and P. Oudemans. 2005a. Botrytis blight in highbush blueberry. Rutgers Cooperative Extension fact sheet NJAES. FS512.

Sciarappa, W. and P. Oudemans. 2005b. Mummy berry: An important disease of highbush blueberry. Rutgers Cooperative Extension fact sheet NJAES. FS511.

Sciarappa, W., S. Polavarapu, R. Holdcraft, and J. Barry. 2005. 2005. Disruption of sexual communication of oriental beetles (Coleoptera: Scarabaeidae) in highbush blueberries with retrievable pheromone sources. Environ. Entomol. 34:54-58.

USDA-NOP. 2006. <http://www.ics-intl.com/nop. htm>.

USDA-NOP. 2002. <http://www.ams.usda.gov/NOP/ indexIE.htm>.

Yarborough, D.E. and M.C. Marra. 1997. Economic thresholds for weeds in wild blueberry fields. Acta Hort. 446:293-301.

Zhang, A., H.T. Facundo, P.S. Robbins, C.E. Linn, Jr., J.L. Hanula, M.G. Villani, and W.L. Roelofs. 1994. Identification and synthesis of female sex pheromone of Oriental beetle, Anomala orientalis (Coleoptera: Scarabaeidae). J. Chem. Ecol. 20:2415-2427. 